MINERALOGIA POLONICA

DOI 10.2478/v10002-007-0011-z

PL ISSN 0032-6267

Vol. 37, No 2, 2006

SHORT NOTE

Wanda WILCZYŃSKA-MICHALIK' ${ }^{1}$ Marek MICHALIK²

\title{
CELESTITE IN THE WEATHERING CRUST ON LIMESTONE EXPOSED TO AN URBAN ATMOSPHERE IN CRACOW (POLAND)
}

\author{
Received October 20, 2006; accepted December 29, 2006
}

Abstract. Celestite containing very low amounts of barium occurs in weathering reaction zones developed on the Pińczów limestone exposed to the polluted atmosphere of Cracow. The mineral occurs both in limestone pore spaces filled with gypsum and in black gypsum crust. The Pińczów limestone contains ca $500 \mathrm{ppm}$ strontium which was released during the reaction with atmospheric pollutants. The nucleation and growth of celestite, requiring significant concentration of components in evaporating solutions, is associated with gypsum crystallization.

Key-words: celestite, weathering in urban atmosphere, black crust, Pińczów limestone, Cracow

\section{INTRODUCTION}

The weathering of rocks used as building material in Cracow has been significantly accelerated in comparison with the weathering of the same or similar rocks in areas remote from the city. High concentrations of atmospheric pollutants have been the cause for both an accelerated weathering rate and the promotion of specific weathering mechanisms. Salt weathering is typical of the Cracow urban area (Wilczyńska-Michalik 2004 and references therein). Reduced emissions of pollutants (especially of dust) during the current period of industrial-plant modernization and of heating systems in the city, has resulted in decreased atmospheric pollution and a shift in the $\mathrm{pH}$ of

\footnotetext{
1 Institute of Geography, Pedagogical Academy, 30-084 Kraków, ul. Podchorążych 2, Poland; e-mail: wmichali@ap.krakow.pl

2 Institute of Geological Sciences, Jagiellonian University, 30-063 Kraków, ul. Oleandry 2a, Poland; e-mail: michalik@geos.ing.uj.edu.pl
} 
precipitation to lower values. Both of these factors are the reason for changes in weathering processes in the urban area during the last few years. The decrease in $\mathrm{pH}$ has increased the aggressiveness of atmospheric precipitation.

Among various visual features related to the atmospheric weathering - granular disintegration, flaking, soiling etc. - the formation of a dark-coloured (usually black) crust of secondary minerals is widespread (e.g. Manecki et al. 1982; Wilczyńska-Michalik 2004). Dark crusts have formed on numerous types of rocks in Cracow, especially on Upper Jurassic limestone, the Libiąż dolomite (Middle Triassic), the Pińczów limestone (Tertiary) and some varieties of sandstone. The morphology of the crust is related to whether the surface concerned is vertical, horizontal or overhanging and to rock properties such as porosity.

Numerous minerals have been noted in the weathered reaction zones in Cracow. In addition to predominant gypsum, other sulphate minerals such as bassanite, hexahydrite, epsomite, melanterite, langbeinite, mirabilite, syngenite, burkeite, celestite, carbonates such as calcite and dolomite, chlorides such as halite and sylvite and nitrates such as nitronatrite and nitrammite may be present (Wilczyńska-Michalik 2004). Minerals can precipitate from rainwater and/or as a result of reaction between atmospheric components and unstable rock minerals. The abundance of newly-formed minerals may reflect various factors, e.g., the compositions of the pollutants and of the weathered rocks and the manner in which a given rock surface is exposed.

Celestite $\left(\mathrm{SrSO}_{4}\right)$ was recorded only in gypsum-bearing weathering zones on the Pińczów limestone (Wilczyńska-Michalik 2004). Wilczyńska-Michalik (2004) suggests that the celesite formed by reaction between strontium from the limestone and atmospheric sulphate. Additional strontium coming from atmospheric pollution cannot be ruled out. Here, we present new data on the chemical composition of the celestite and of the Pińczów limestone and discuss the origin of the celestite.

\section{MATERIAL STUDIED}

During its renovation in 1999, samples of Pińczów limestone were taken from stone details of St. Mary's Church in Cracow (Figs 1 and 2). All of the samples contain gypsum in pore-spaces and in the weathered crust formed on their surfaces (Fig. 3).

The Pińczów limestone is a well-known building material commonly used in Poland for carved details and sculptures. The rock hardens after excavation from the source quarry. The porosity of this limestone is usually high, ranging from above $35 \%$ in coarse-grained rock to ca 25\% in fine-grained rock (Kozłowski et al. 1990; Bromowicz 2001). Because of this high porosity, gypsum tends to crystallize in pore spaces causing granular disintegration. Haber et al. (1988) and Kozłowski et al. (1990) determined the relationship between the sizes of grains and pore-spaces in the rock and resistance to weathering. 
Samples were studied using optical microscopy, scanning electron microscopy and energy depressive spectrometry (SEM-EDS: HITACHI S-4700 microscope with

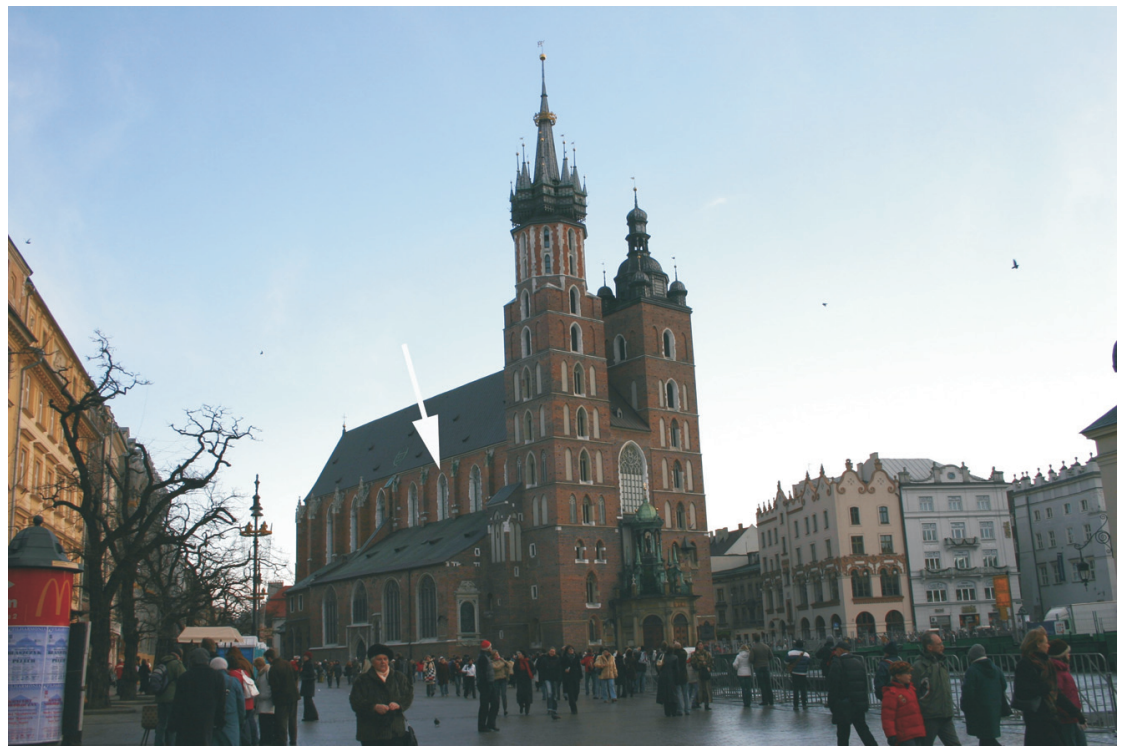

Fig. 1. St. Mary's Church, Cracow. Arrow indicates a sampling site

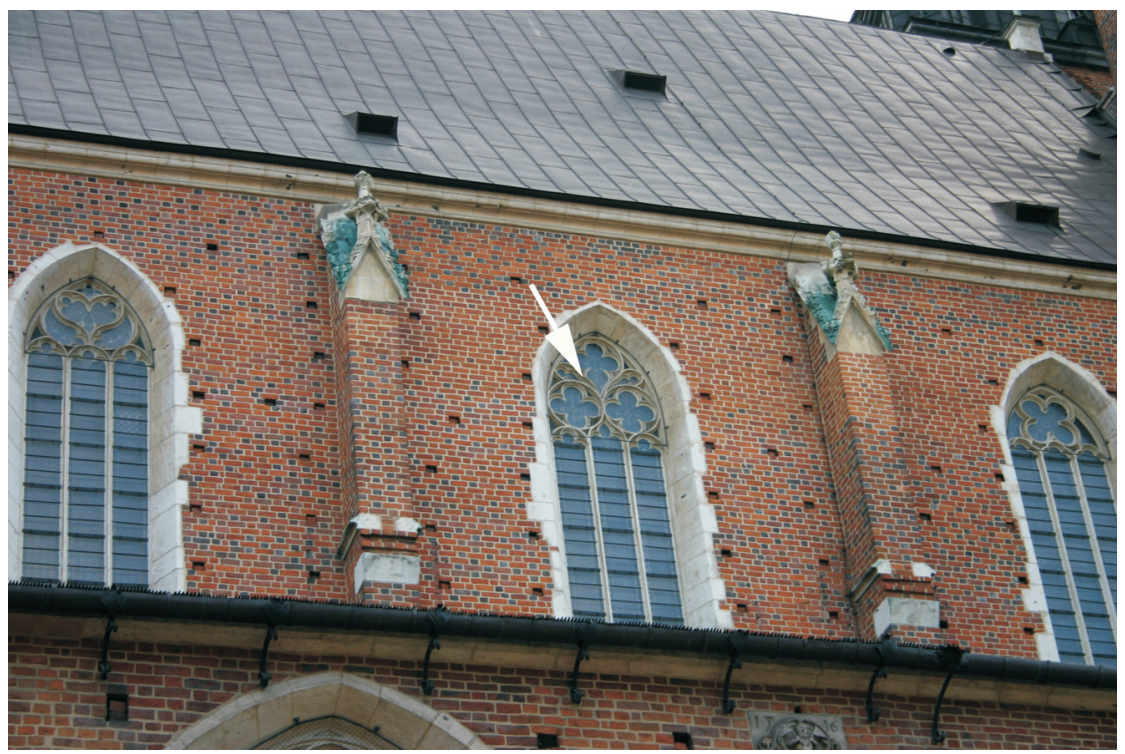

Fig. 2. St. Mary's Church, Cracow. Arrow indicates a sampling site 
THERMO NORAN Vantage analytical system and JEOL 5410 microscope with Voyager analytical system), X-ray diffraction (Philips APD X'Pert diffractometer) and chemical analyses (ICP-ES and ICP-MS).

The SEM-EDS analyses were performed at the Laboratory of Scanning Microscopy of Biological and Geological Sciences of the Faculty of Biology and Earth Sciences of the Jagiellonian University and chemical analyses at the ACME laboratories in Canada.

\section{RESULTS}

The analyzed limestone is a medium-grained rock composed of bioclasts cemented by minor coarse crystalline calcite. The pore spaces in the limestone are partly filled with fine crystalline gypsum (Fig. 3). The rock surface exposed to the atmosphere is covered by a gypsum crust ca $0.5 \mathrm{~mm}$ thick (Fig. 3). Because of blistering and scaling, the gypsum crust is typically discontinuous. The crust is composed of elongated, platy gypsum crystals (Fig. 4 and 5). Larger gypsum crystals are oriented perpendicular to the limestone surface (Fig. 3) and smaller crystals form random intergrowths (Fig. 4). Dissolution voids can be seen on the surfaces of larger crystals (Fig. 4). Between the gypsum crystals, atmospheric dust is present both as natural mineral grains and anthropogenic particles (Fig. 5).

The chemical composition of fresh Pińczów limestone from the source quarries is presented in Table 1. The strontium content is close to $500 \mathrm{ppm}$ and that of barium below $10 \mathrm{ppm}$. The molar Sr/Ba ratio varies around 100 (Table 1).

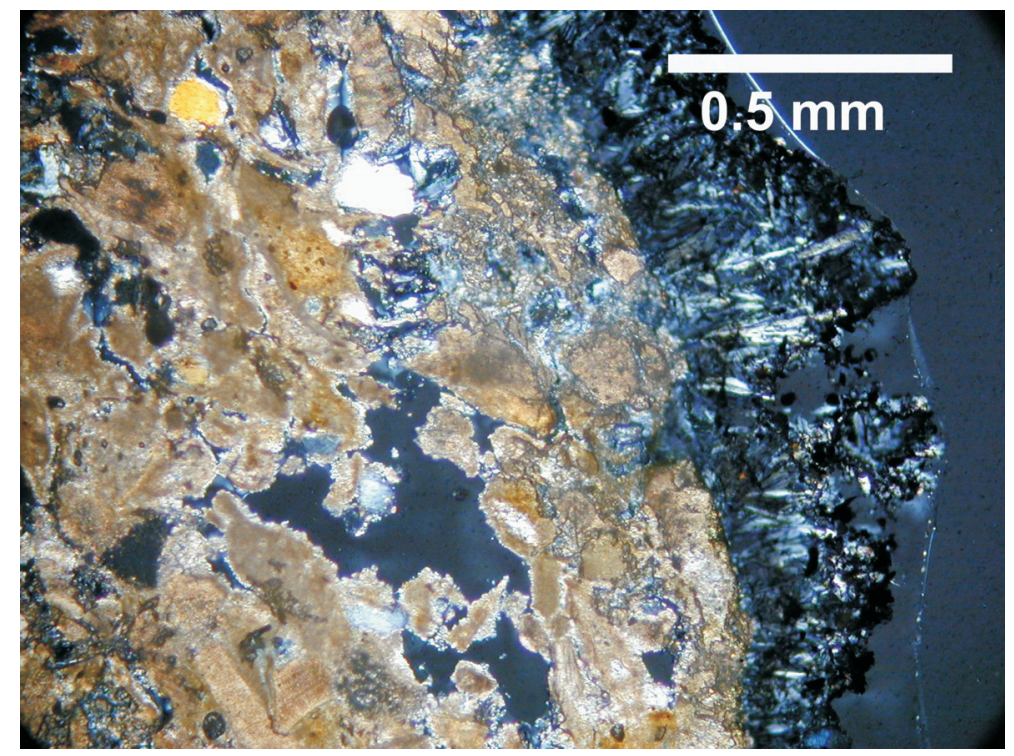

Fig. 3. Pińczów limestone sample with black gypsum crust and gypsum crystallizing in pore spaces. Crossed polars 


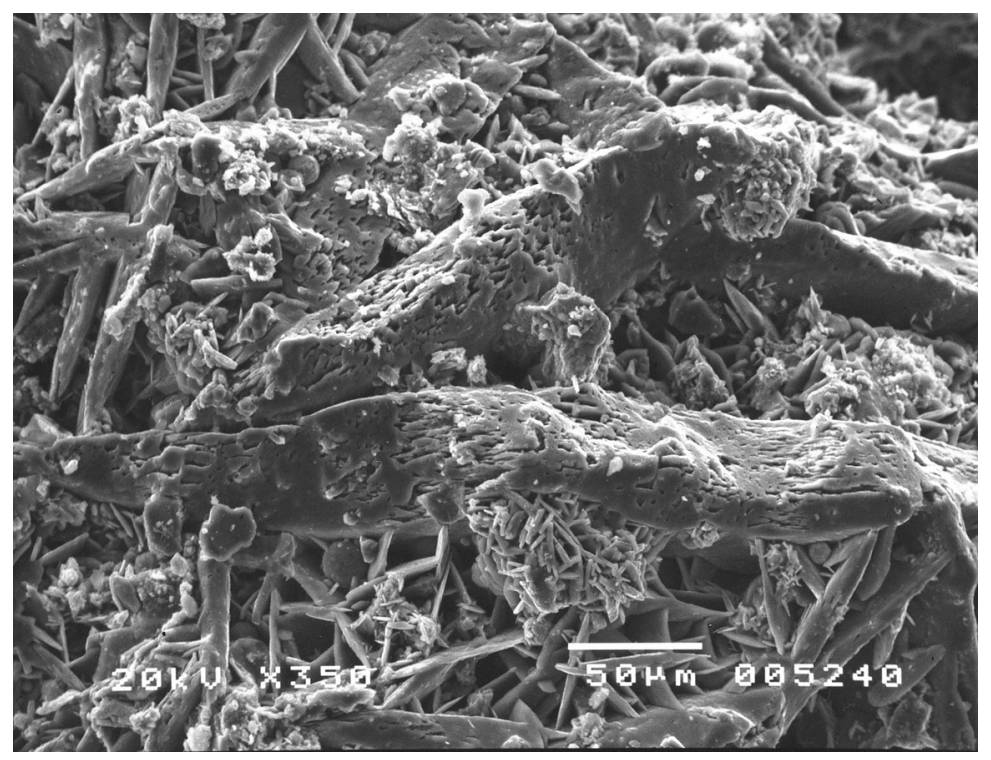

Fig. 4. Platy gypsum crystals of various sizes. Dissolution voids are visible on larger crystals. SEM, SE image

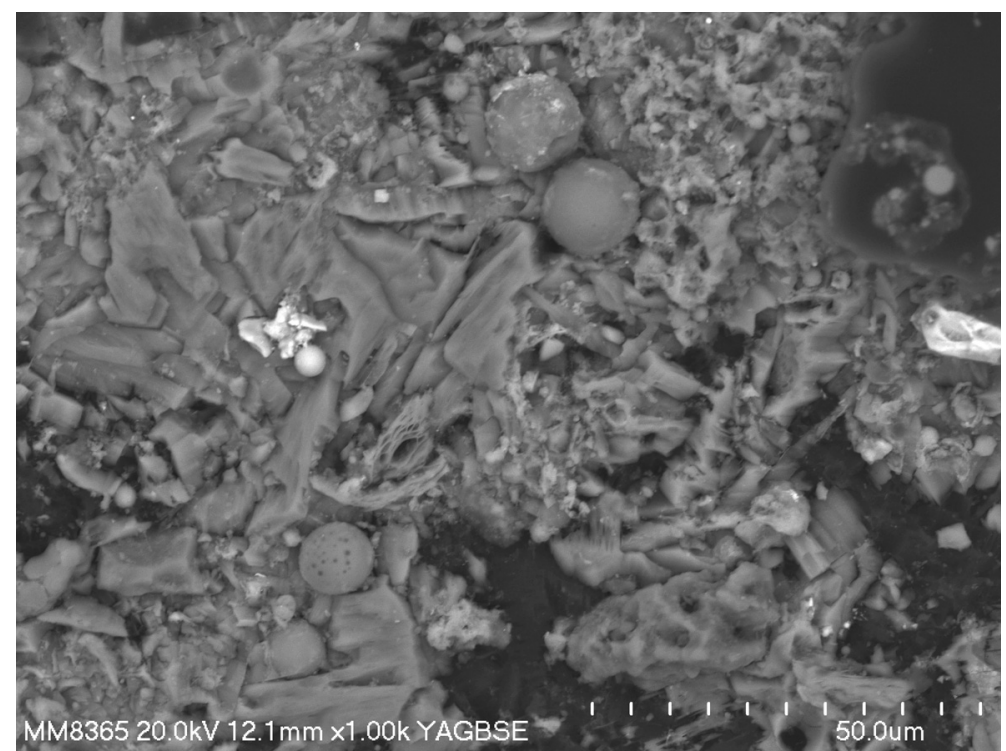

Fig. 5. Gypsum crystals in black crust. Spherical aluminosilicate dust particles; bright particle is rich in Fe. SEM, BSE image

Celestite occurs within gypsum nests formed in pore spaces or in black gypsum crust (Fig. 6 and 7) as irregular or rounded aggregates up to $10 \mu \mathrm{m}$ in size. Larger $(<100 \mu \mathrm{m})$ celestite aggregates are scarce (Fig. 8). Locally, celestite is abundant (Fig. 7). The mineral is rare in the weathering zone on the limestone though greater amounts were noted in places. 
Chemical composition of the Pińczów limestone

\begin{tabular}{|c|c|c|}
\hline Component (in wt.\%; Ba and Sr in ppm) & Sample 1 & Sample 2 \\
\hline $\mathrm{SiO}_{2}$ & 1.80 & 1.69 \\
\hline $\mathrm{Al}_{2} \mathrm{O}_{3}$ & 0.19 & 0.19 \\
\hline $\mathrm{Fe}_{2} \mathrm{O}_{3}$ & 0.17 & 0.17 \\
\hline $\mathrm{MgO}$ & 0.77 & 0.76 \\
\hline $\mathrm{MnO}$ & 0.01 & 0.01 \\
\hline $\mathrm{CaO}$ & 53.91 & 53.74 \\
\hline $\mathrm{Na}_{2} \mathrm{O}$ & 0.06 & 0.07 \\
\hline $\mathrm{K}_{2} \mathrm{O}$ & 0.03 & 0.02 \\
\hline $\mathrm{TiO}_{2}$ & 0.01 & $<0.01$ \\
\hline $\mathrm{P}_{2} \mathrm{O}_{5}$ & 0.08 & 0.08 \\
\hline LOI & 42.9 & 43.1 \\
\hline Tot. S & 0.04 & 0.01 \\
\hline $\mathrm{Sr}$ & 492 & 494 \\
\hline $\mathrm{Ba}$ & 7 & 9 \\
\hline $\mathrm{Sr} / \mathrm{Ba}$ (molar ratio) & 110 & 86 \\
\hline
\end{tabular}

TABLE 2

Chemical composition of celestite (EDS spot analyses)

\begin{tabular}{lcccccccc}
\hline & M1b-1-2 & M1b-2-2 & M1b-8-1 & M1b-8-3 & M1b-1-4 & M1b-2-3 & M1b-3-1 & M1b-3-2 \\
\hline $\mathrm{SrO}$ & \multicolumn{7}{c}{ Oxides [wt. $\%]$} \\
$\mathrm{CaO}$ & 51.80 & 51.90 & 54.40 & 53.70 & 52.53 & 53.98 & 53.42 & 53.05 \\
$\mathrm{BaO}$ & 1.18 & 0.55 & 0.34 & 0.35 & 1.09 & 0.82 & 0.56 & 0.67 \\
$\mathrm{SO}_{3}$ & 0.86 & 1.24 & 1.05 & 0.74 & 0.85 & 0.24 & 1.51 & 0.60 \\
$\mathrm{Total}$ & 46.16 & 46.32 & 44.21 & 45.21 & 45.53 & 44.78 & 44.51 & 45.68 \\
\hline & 100 & 100.01 & 100 & 100 & 100 & 99.82 & 100 & 100 \\
\hline $\mathrm{Sr}^{2+}$ & 0.886 & 0.889 & 0.957 & 0.932 & 0.906 & 0.940 & 0.936 & 0.914 \\
$\mathrm{Ca}^{2+}$ & 0.037 & 0.017 & 0.011 & 0.011 & 0.035 & 0.027 & 0.018 & 0.021 \\
$\mathrm{Ba}^{2+}$ & 0.010 & 0.014 & 0.013 & 0.009 & 0.010 & 0.003 & 0.018 & 0.007 \\
$\mathrm{~S}^{6+}$ & 1.022 & 1.027 & 1.007 & 1.016 & 1.017 & 1.009 & 1.009 & 1.019 \\
$\mathrm{Sr}^{2+}$ Ba (molar ratio) & 89 & 62 & 77 & 108 & 91 & 332 & 52 & 131 \\
\hline
\end{tabular}


The chemical composition of the celestite is generally stable. The fact that the $\mathrm{Sr} / \mathrm{Ba}$ molar ratio is variable within a broad range from about 50 to over 300 (Table 2) indicates that the celestite is virtually pure with very limited barium substitution.

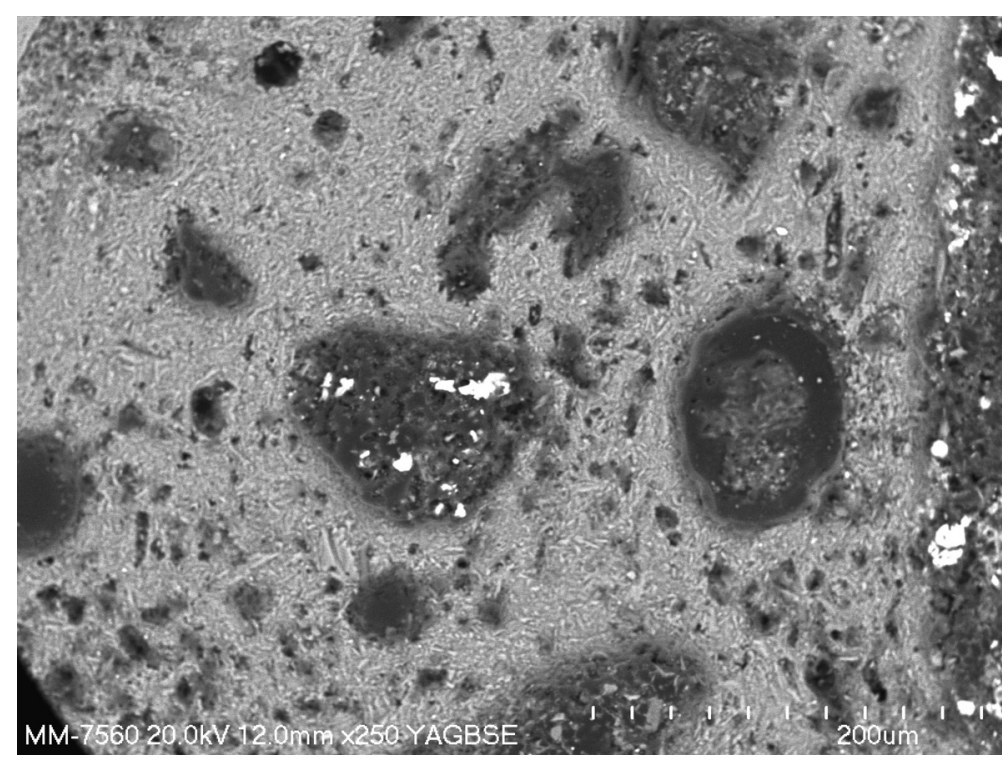

Fig. 6. Celestite (bright irregular patches) inside voids filled with gypsum and in black crust. SEM, BSE image

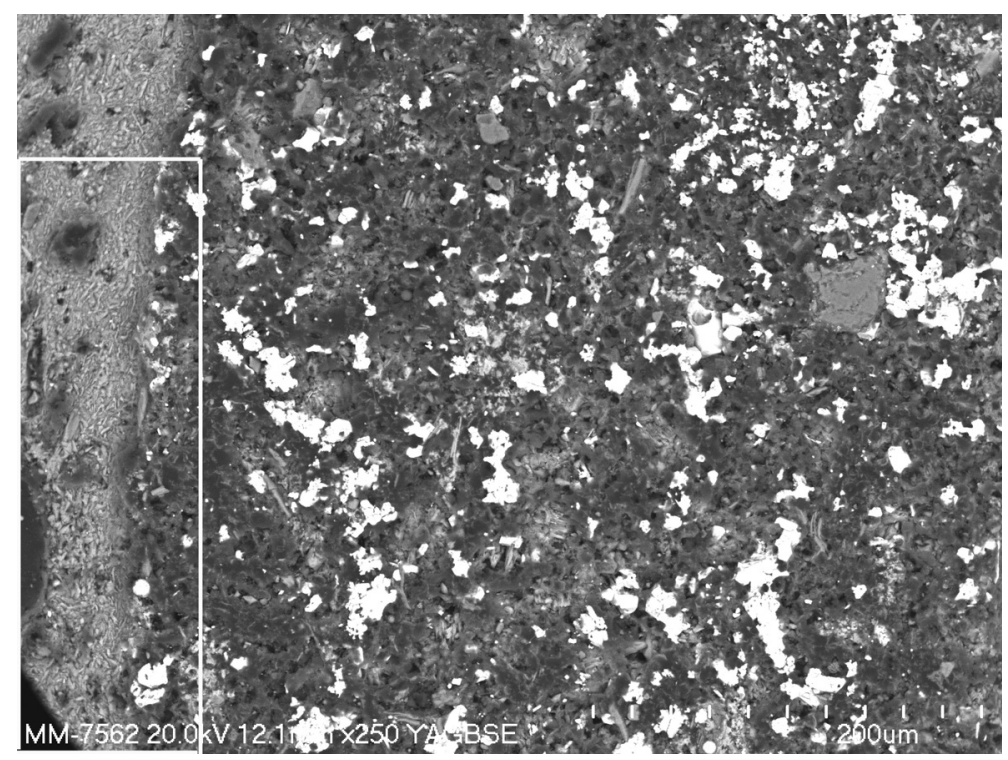

Fig. 7. Celestite (bright patches) dispersed inside gypsum crust. Rectangle - area covered by Fig. 6 . SEM. BSE image 


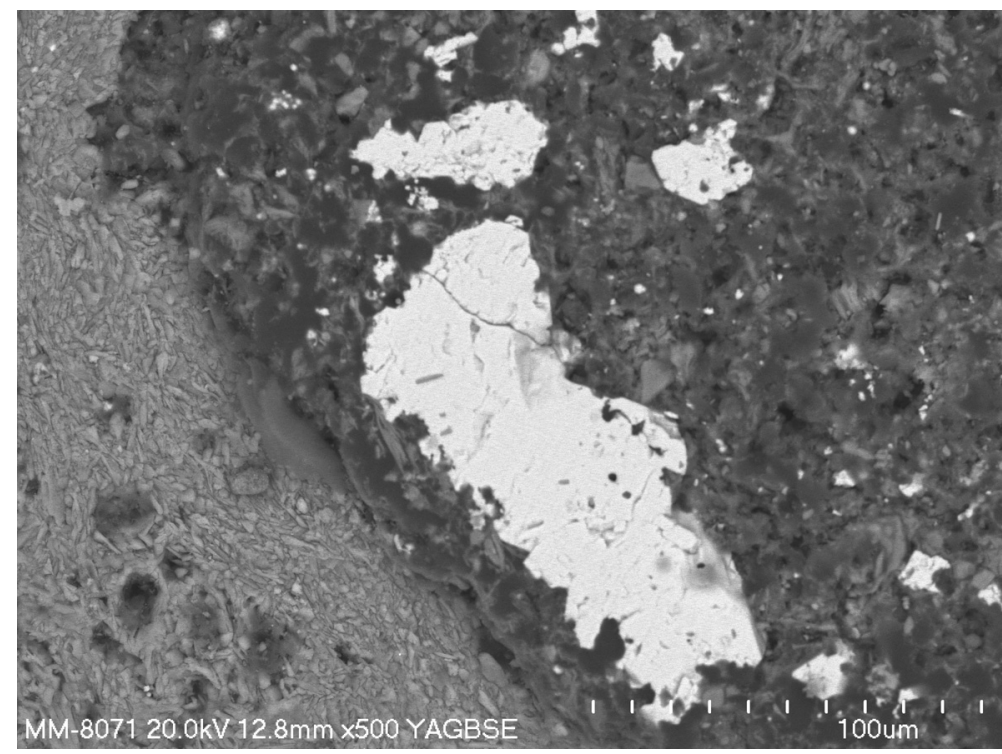

Fig. 8. Coarse celestite aggregates within gypsum crust. SEM, BSE image

\section{DISCUSSION AND CONLUSIONS}

Celestite can be present in trace amounts in carbonate rocks. Its formation is usually related to diagenetic processes (e.g. Melim et al. 2002; Fu et al. 2004). In the material described here, celestite is present exclusively within gypsum aggregates formed inside pore spaces of the Pińczów limestone or within black gypsum crust formed on the rock surface. That it is a secondary mineral due to reaction between rock components and polluted urban atmosphere is indicated.

Although different rock types exposed to reaction with polluted atmosphere have been studied in detail (Wilczyńska-Michalik 2004 and references therein), celestite was recorded only in reaction zones on the Pińczów limestone. This suggests that strontium is derived from the limestone. Although the deposition of strontium from atmospheric pollution has bee described in the literature (e.g., Probst et al. 2000), the absence of celestite in reaction zones developed on other rock types indicates that this source of strontium is of negligible importance in Cracow. During calcite decomposition in the Pińczów limestone containing ca $500 \mathrm{ppm}$ Sr and the formation of gypsum due to reaction between this calcium and sulphate ions in atmospheric pollution, strontium was released.

Nucleation of both celestite and barite requires high supersaturation. Supersaturation is about two orders higher for barite than for celestite (Sánchez-Pastor 2006). Supersaturation can be attained during gypsum crystallization and evaporation of solution present on the rock surface. An increase in ion concentrations during gypsum crystallization is evidenced by the formation of protodolomite (Wilczyńska-Michalik 
2004) according to the so-called "urban model for dolomite precipitation" (Rodríguez-Navarro et al. 1997). Local variations in solution compositions and in the conditions of celestite precipitation resulted, perhaps, in variations in the barium content of the celestite.

Celestite precipitation can also be related to bacteria responsible for the concentrating of various elements, e.g., Sr (Douglas 2004). Although this possibility is not supported here by analytical data, it can be considered likely. The role of bacteria needs more detailed study.

A high concentration of celestite in the gypsum crust can be related to its lower solubility in comparison to gypsum. Celestite is relatively resistant during weathering (Czerewko et al. 2003). Evidences of gypsum dissolution in black crust support this suggestion.

Local concentrations of celestite on rock surfaces can be linked to variable conditions caused by differences in degrees of washing by rainwater and of sun exposure, etc. Microbial activity cannot be ruled out.

Acknowledgments. This work was supported by Committee for Scientific Research (KBN) grant No. 6PO4D 01717 and by Jagiellonian University research fund. The authors would like to thank Prof. P. Kennan for the language corrections.

\section{REFERENCES}

BROMOWICZ 2001: Application of the building stones of the Cracow area for the masonary reconstructions the evaluation of perspectives (in Polish, English summary). Gospodarka Surowcami Mineralnymi $17,1,5-72$.

CZEREWKO M. A., CRIPPS J. C., REID J. M., DUFFELL C. G., 2003: Sulfur species in geological materials sources and quantification. Cement and Concrete Composites 25, 657-671.

DOUGLAS S., 2004: Microbial biosignatures in evaporative deposits: Evidence from Death Valley, California. Planetary and Space Science 52, 223-227.

FU Q., QING H., BERGMAN K. M., 2004: Dolomitized calcrete in the Middle Devonian Winnipegosis carbonate mounds, subsurface of south-central Saskatchewan, Canada. Sedimentary Geology 168, 49-69.

HABER J., HABER H., KOZŁOWSKI R., MAGIERA J., PŁUSKA J., 1988: Air pollution and decay of architectural monuments in the city of Cracow. Durability of Building Materials 5, 499-547.

KOZŁOWSKI r., MAGIERA J., WEBER J., HABER J., 1990: Decay and conservation of Pińczów porous limestone; I. Lithology and weathering. Studies in Conservation 35, 205-221.

MANECKI A., CHODKIEWICZ M., KONOPACKI S., 1982: Results of mineralogical investigations of the dimensions and causes of the destruction of stone elements in Cracow's monumental buildings (in Polish, English summary). Sozologia i Sozotechnika 35, 7-34.

MELIM L. A., WESTPHAL H., SWART P. K., EBERLI G. P., MUNNECKE A., 2002: Questioning carbonate diagenetic paradigms: evidence from the Neogene of Bahamas. Marine Geology 185, 27-53.

PROBST A., GH'MARI A. E., AUBERT D., FRITZ B., MCNUTT R., 2000: Strontium as a tracer of weathering processes in a silicate catchment polluted by acid atmospheric input, Strengbach, France. Chemical Geology 170, 203-217.

RODRÍGUEZ-NAVARRO C., SEBASTIAN E., RODRÍGUEZ-GALLEGO M., 1997: An urban model for dolomite precipitation: authigenic dolomite on weathered building stones. Sedimentary Geology 109, 1-11.

SÁNCHEZ-PASTOR N., PINA C. M., FERNÁNDEZ-DÍAZ L., 2006: Relationships between crystal morphology and composition in the $(\mathrm{Ba}, \mathrm{Sr}) \mathrm{SO}_{4}-\mathrm{H}_{2} \mathrm{O}$ solid solution-aqueous solution system. Chemical Geology 225, 266-277. 
WILCZYŃSKA-MICHALIK W., 2004: Influence of atmospheric pollution on the weathering of stones in Cracow monuments and rock outcrops in Cracow, Cracow-Częstochowa Upland and the Carpathians. Wydawnictwo Naukowe Akademii Pedagogicznej, Kraków, p. 1-247.

Wanda WILCZYŃSKA-MICHALIK, Marek MICHALIK

\section{CELESTYN W NASKORUPIENIACH WIETRZENIOWYCH NA WAPIENIU ROZWINIĘTYCH W ATMOSFERZE MIEJSKIEJ W KRAKOWIE (POLSKA)}

\section{Streszczenie}

Celestyn z niewielką zawartością baru występuje w strefach reakcji rozwiniętych na wapieniu pińczowskim wystawionym na działanie zanieczyszczonej atmosfery w Krakowie. Minerał ten występuje zarówno w porach wypełnionych gipsem, jak i w czarnych naskorupieniach gipsowych. Wapień pińczowski zawiera około 500 ppm strontu, który jest uwalniany podczas reakcji z zanieczyszczeniami atmosfery. Zarodkowanie i wzrost celestynu wymagające znacznej koncentracji składników podczas parowania roztworów są związane z krystalizacją gipsu. 